\title{
Iron compounds and a magnetic field as the conditioning agents for municipal sewage sludge
}

\author{
Kamila Hrut $^{1, *}$, and Tomasz Kamizela ${ }^{1}$ \\ ${ }^{1}$ Częstochowa University of Technology, Faculty of Infrastructure and Environment, Institute \\ of Envronmental Engineering, ul. Brzeźnicka 60A, 42 - 201 Częstochowa, Poland
}

\begin{abstract}
The purpose of the research was to determine the possibility of using a magnetic field as a factor supporting the conditioning of municipal sewage sludge prepared using a chemical method. In order to condition the sludge, PIX 113 iron coagulant or $\mathrm{Fe}_{3} \mathrm{O}_{4}$ nanoparticles were used. Two types of organic flocculants: medium cationic Superfloc ${ }^{\circledR}$ C-494 and high cationic Superfloc ${ }^{\circledR}$ C-496 were also applied. For the various test combinations a capillary suction time test was performed, the specific resistance to filtration and the final filtration of the filter cakes were determined. For selected combinations, a quality of supernatants analysis was also performed, the measure of which was the COD values. The results show, that in the dual chemical conditioning method, the use of PIX 113 coagulant was more favorable than the nanoparticles $\mathrm{Fe}_{3} \mathrm{O}_{4}$. The influence of a magnetic field on the susceptibility to the dewatering of the tested sludge was variable, depending on process parameters such as the flow direction and flow rate through the solenoid. The type of polyelectrolyte used in the conditioning method with magnetic field action was also significant.
\end{abstract}

\section{Introduction}

The municipal infrastructure, including a sewage network, is an element of a wider system referred to as water and wastewater management. An element of this system is also the wastewater treatment plant, which reduces the negative impact of pollution on the environment. Wastewater treatment is a waste process that generates sewage sludge. The amount of municipal sewage sludge produced in Poland in 2017 was over 568 thousand tonnes of dry solids [1]. Sludge hydration, in its original form, is even over $99 \%$. This determines a large volume of sludge, thus thickening and dewatering are key processes in sludge management. This high hydration affects a large volume of sludge, thus thickening and dewatering are the key processes in sludge management. The composition and properties of the sludge additionally hinder the reduction of hydration, therefore their conditioning is used. Conditioning methods are generally methods that limit the strength of water binding to solid phase particles, including structuring or oxidizing agents [2 - 4]. There are many wellknown and studied methods of conditioning based on the use of chemical, physical and

\footnotetext{
*Corresponding author: kamila.hrut@is.pcz.pl
} 
biological agents and their combinations. Currently, a chemical conditioning method basedon the dosing of polyelectrolyte is commonly used $[5,6]$.

One of the many conditioning agents is the magnetic field [7]. The magnetic field has also been applied in many fields of science, including process engineering, environmental engineering and biotechnology. Siadaty et al. studied the influence of the magnetic field on the particle collection performance of a high efficiency stairmand cyclone [8]. Zao at al. used the phenomenon of magnetic levitation for separating multiple mixed plastics [9]. Several literature reports refer to the use of magnetic fields in wastewater treatment technologies on the basis of its effect on activated sludge. It is documented that it is possible to enhance biochemical processes [10], formaldehyde biodegradation [11] or nitrification [12]. The spectrum of application of the magnetic field can effectively be extended by the addition of magnetic particles. This approach enables effective magnetic field action, e.g. in environmental technologies. Sedimentation and filtration wastewater suspensions [13], sewage sludge [14] or starch granules [15] mixed with ferric coagulant or magnetic nanoparticles allows increasing the efficiency of separation processes. The significant advantage of using nanoparticles is their properties and high efficiency of separation in a magnetic field. The potential use of nanoparticles may occur in the petroleum industry or water and wastewater treatment. It is possible to use nanoparticles for the isolation of selected crude oil components, and emulsion destabilization [16], for removing heavy metals [17] and reducing fouling in a magnetic membrane bioreactor [18].

In this study the possibility of using a magnetic field as a factor supporting sludge conditioning was investigated. The aim of the research was also to determine the suitability of dual chemical conditioning. The dual conditioning method was based on the sequential use of a polyelectrolyte and iron coagulant or a polyelectrolyte and nanoparticle iron oxide. An induction coil was used as the source of the magnetic field. The influence of the direction and rate of the sludge flow through the coil and type polyelectrolyte on the filtration propertiesof digested sludge also been tested.

\section{Experimental}

\subsection{Materials}

The analyzed samples of digested sludge were collected from a sewage treatment plant located in the Silesian province (Poland). The sewage treatment plant functioning in a UCT (University of Cape Town) technological system operates at a sewage inflow of 45 thousand cubic meters per day. The studied digested sludge was taken from the heat exchanger installation. Sampling took place from November 2017 to February 2018. The dry solids (DS) and volatile solids (VS) of sludge was respectively $20,5 \mathrm{~g} / \mathrm{L}( \pm 3,4 \mathrm{~g} / \mathrm{L})$ and $40,8 \%$ DS $( \pm 9,8 \% \mathrm{DS})$. The $\mathrm{pH}$ and alkalinity were $7,5( \pm 0,4)$ and $3159 \mathrm{mg} \mathrm{CaCO}_{3} / \mathrm{L}( \pm 784 \mathrm{mg}$ $\left.\mathrm{CaCO}_{3} / \mathrm{L}\right)$.

\subsection{Analyses}

The characteristics of the tested sludge were determined on the basis of dry solids (DS), volatile solids (VS), pH, alkalinity (Alk), all measured according to standard methods for the examination of water and wastewater (APHA, 2005).

To characterize the susceptibility to dewatering of the conditioned sludge, measurements of capillary suction time (CST) and specific resistance to filtration were performed $[19,20]$. 
The specific resistance to filtration (r) was determined on a vacuum filter. The 100 mlof sludge was filtered for 30 minutes at $85 \mathrm{kPa}$ (Whatman ${ }^{\circledR} 1$ filter paper).

In order to determine the influence of the conditioning methods on the chemical oxygen demand in supernatants, a centrifuge (15 minutes at $1200 \mathrm{rcf}$ ) was used. No effluent from vacuum filtration was used. It was considered that the centrifugation allows for a better comparison of the effects of these methods based on the quality of the supernatant than based on cake filtration on filter paper. The COD content was measured with the use of Hach test tubes and a Hach Lange DR 5000 spectrophotometer. Prior to COD measurement, $50 \mathrm{ml}$ samples of supernatant were homogenized for 60 seconds using an IKA T10 basic homogenizer.

\subsection{Experimental devices}

The length of the solenoid used was $1=220 \mathrm{~mm}$, the inner diameter of the bobbin was $\mathrm{d}_{\mathrm{C}}=33.0 \mathrm{~mm}$, where the wire diameter was $\mathrm{d}_{\mathrm{W}}=0.40 \mathrm{~mm}$, the number of turns $\mathrm{z}=30000.0$, coil resistance $\mathrm{R}=964 \Omega$, current supply $\mathrm{I}=0.228 \mathrm{~A}$, power $\mathrm{P}=50 \mathrm{~W}$. The magnetic field distribution inside the solenoid was measured with a Teslameter Phywe sensor. The maximum value of induction was $0.04 \mathrm{~T}$. A schematic of the experimental apparatus is presented in Fig. 1.

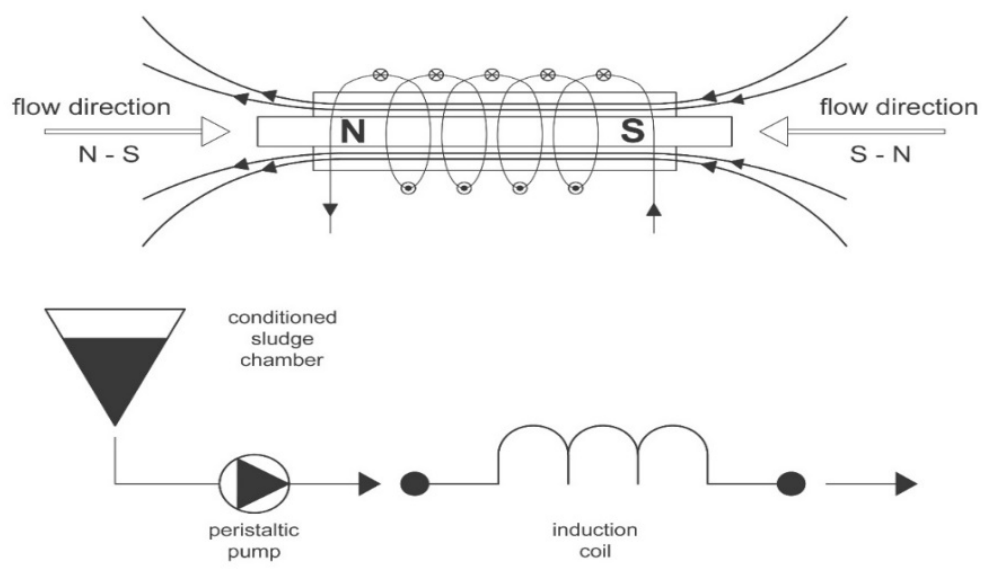

Fig. 1. Schematic of the experimental apparatus.

In the middle of the bobbin a PVC pipe (internal diameter $d_{P}=25.0 \mathrm{~mm}$ ) was placed. The conditioned sludge was pumped through the pipe. The volume of the pipe (also the amount of exposed sludge), measured on the length of the coil, was $\mathrm{V}_{\mathrm{S}} \approx 110 \mathrm{~mL}$. A Masterflex I/P type Peristaltic pump was used. The sludge was pumped at two flow rates $\mathrm{q}_{1}$ $=1 \mathrm{~L} / \mathrm{min}$. and $\mathrm{q}_{2}=2 \mathrm{~L} / \mathrm{min}$. Based on the flow rate $\left(\mathrm{q}_{1}\right.$ and $\left.\mathrm{q}_{2}\right)$ through the coil and volume $\mathrm{V}_{\mathrm{S}}$, the exposure time in the magnetic field was calculate at, $\mathrm{t}_{1}=1.2 \mathrm{~s}$ and $\mathrm{t}_{2}=0.6 \mathrm{~s}$ respectively.

\subsection{Experiment}

In order to prepare the sludge, the following conditioning agents was applied:

- medium-cationic polyelectrolyte Superfloc ${ }^{\circledR}$ C-494 in a concentration of $0.1 \%$

- high-cationic polyelectrolyte Superfloc ${ }^{\circledR}$ C-496 in a concentration of $0.1 \%$

- ferric coagulant PIX 113 (iron content 11.8\%) 
- nanoparticle iron oxide $\mathrm{Fe}_{3} \mathrm{O}_{4}$ (iron content 72.36\%, Sigma - Aldrich, 637106, CAS 131761-9)

- magnetic field (induction 0,04T)

The tested sludge $(1.0 \mathrm{~L})$ was mixed with chemical agents using a paddle stirrer with a diameter of $10.0 \mathrm{~cm}$ (400 rpm, 20 seconds, for each dosed chemical agent). PIX 113 coagulant was dosed in a constant volume dose of $4 \mathrm{~mL} / \mathrm{L}\left(0.3 \pm 0.02 \mathrm{~kg} / \mathrm{kg}_{\mathrm{DM}}\right)$, which corresponded to an iron dose of $35.4 \mathrm{~g} / \mathrm{kg}_{\mathrm{DM}}$. The same amount of iron was used by dosing $\mathrm{Fe}_{3} \mathrm{O}_{4}$ nanoparticles, which corresponded to a mass dose of $49.92 \pm 2.13 \mathrm{~g} / \mathrm{kg}$ DM. The optimal polyelectrolyte doses were determined by CSK test and were $3.98 \pm 0.37 \mathrm{~g} / \mathrm{kg}_{\mathrm{DM}}$ and $4.62 \pm 0.51 \mathrm{~g} / \mathrm{kg}_{\mathrm{DM}}$ respectively for Superfloc C - 494 and Superfloc C 496. For combinations using a magnetic field, polymer doses of $20 \%$ less than optimal were used (3.18 $\mathrm{g} / \mathrm{kg}_{\mathrm{DM}}$ and $3.69 \mathrm{~g} / \mathrm{kg}_{\mathrm{DM}}$ respectively). Dose reduction was dictated by the use of a chemical agent and a magnetic field. It was intended to demonstrate a reduction in the polymer dose when the sludge was subjected to additional exposure to the magnetic field. The research was divided into 4 steps, which differed in the type of chemical conditioning agents used (Table 1).

Table 1. The sequence of chemical conditioning of the tested sludge.

\begin{tabular}{|c|c|c|c|}
\hline \multirow{4}{*}{$\begin{array}{l}\text { The addition sequence } \\
\text { of chemical } \\
\text { conditioning agents }\end{array}$} & Step 1 & & $\begin{array}{l}\text { PIX } 113 \text { ferric coagulant } \\
\text { polyelectrolyte Superfloc C - } 494\end{array}$ \\
\hline & Step 2 & $\begin{array}{l}\text { 1) } \\
\text { 2) }\end{array}$ & $\begin{array}{l}\text { PIX } 113 \text { ferric coagulant } \\
\text { polyelectrolyte Superfloc C - } 496\end{array}$ \\
\hline & Step 3 & 1) & $\begin{array}{l}\mathrm{Fe}_{3} \mathrm{O}_{4} \text { ferric nanoparticles } \\
\text { polyelectrolyte Superfloc C - } 494\end{array}$ \\
\hline & Step 4 & 1) & $\begin{array}{l}\mathrm{Fe}_{3} \mathrm{O}_{4} \text { ferric nanoparticles } \\
\text { polyelectrolyte Superfloc C - } 496\end{array}$ \\
\hline
\end{tabular}

The sludge, after chemical conditioning was exposed to a magnetic field generated by a solenoid. As part of each step of the study, several combinations were performed that also included the method of exposure to the magnetic field (Table 2).

Table 2. Combinations of the conditioning of sludge.

\begin{tabular}{|c|c|c|}
\hline non- prepared sludge & combination 0 & - \\
\hline \multirow{2}{*}{$\begin{array}{l}\text { sludge conditioned } \\
\text { only polyelectrolyte }\end{array}$} & combination A & optimal dose of polyelectrolyte \\
\hline & combination A1 & polyelectrolyte dose reduced by $20 \%$ \\
\hline $\begin{array}{l}\text { sludge dually } \\
\text { conditioned }\end{array}$ & combination $\mathrm{B}$ & $\begin{array}{c}\text { ferric coagulant/nanoparticles }+ \text { reduced dose } \\
\text { of polyelectrolyte }\end{array}$ \\
\hline \multirow{4}{*}{$\begin{array}{c}\text { sludge dually } \\
\text { conditioned } \\
\text { - } \quad \text { and exposed } \\
\text { to a magnetic field }\end{array}$} & combination $\mathrm{C} 1$ & - flow $\mathrm{S}-\mathrm{N}, \mathrm{q}_{1}=1.0 \mathrm{~L} / \mathrm{min} ., \mathrm{t}_{1}=1.2 \mathrm{~s}$ \\
\hline & combination $\mathrm{C} 2$ & - flow $\mathrm{S}-\mathrm{N}, \mathrm{q}_{2}=2.0 \mathrm{~L} / \mathrm{min} . \mathrm{t}_{2}=0.6 \mathrm{~s}$ \\
\hline & combination D1 & - flow $\mathrm{N}-\mathrm{S}, \mathrm{q}_{1}=1.0 \mathrm{~L} / \mathrm{min} ., \mathrm{t}_{1}=1.2 \mathrm{~s}$ \\
\hline & combination D2 & - flow $\mathrm{N}-\mathrm{S}, \mathrm{q}_{2}=2.0 \mathrm{~L} / \mathrm{min}, \mathrm{t}_{2}=0.6 \mathrm{~s}$ \\
\hline
\end{tabular}

\section{Results}

On the basis of the CST test (Table 3), it should be noted that the sludge dual-conditioned using PIX 113 coagulant (combination B, step 1 - 2) was characterized by a lower capillary time compared to thesamples prepared exclusively with polyelectrolyte (combination A - 
A1). The effect of the magnetic field on the CST values was variable, the most favorable results were noted for sediments conditioned with PIX 113 ferric coagulant and polyelectrolyte $\mathrm{C}-494$, in the C1combination. The use of iron nanoparticles (step 3 - 4, combinations B - D2) adversely affected the value of this parameter.

Based on the value of the specific resistance of filtration (Fig. 2), it was concluded that the sludge prepared dually with the use of PIX 113 coagulant (step 1-2) was characterized by the best susceptibility to cake filtration. The effects of sludge exposure on the magnetic field were dependent on processing parameters, such as the direction and rate of sludge flow through the solenoid and the type of polyelectrolyte. The most beneficial effects were achieved for the $\mathrm{C} 1$ combination, for the sludge conditioned by PIX 113 and polyelectrolyte C - 494.

Table 3. Cappilary suction time of conditioned sludge.

\begin{tabular}{|c|c|c|c|c|}
\hline \multirow{2}{*}{ Combination } & \multicolumn{4}{|c|}{ CST, s } \\
\cline { 2 - 5 } & Step 1 & Step 2 & Step 3 & Step 4 \\
\hline 0 & $1566 \pm 132$ & $1463 \pm 109$ & $1232 \pm 98$ & $1342 \pm 126$ \\
\hline A & $78 \pm 16$ & $72 \pm 11$ & $71 \pm 15$ & $68 \pm 12$ \\
\hline A1 & $198 \pm 21$ & $165 \pm 27$ & $247 \pm 35$ & $173 \pm 23$ \\
\hline B & $69 \pm 7$ & $74 \pm 13$ & $251 \pm 31$ & $181 \pm 28$ \\
\hline C1 & $51 \pm 8$ & $61 \pm 4$ & $269 \pm 39$ & $223 \pm 32$ \\
\hline C2 & $89 \pm 15$ & $72 \pm 11$ & $285 \pm 43$ & $251 \pm 30$ \\
\hline D1 & $121 \pm 23$ & $54 \pm 7$ & $239 \pm 28$ & $205 \pm 21$ \\
\hline D2 & $132 \pm 27$ & $69 \pm 11$ & $275 \pm 36$ & $242 \pm 39$ \\
\hline
\end{tabular}

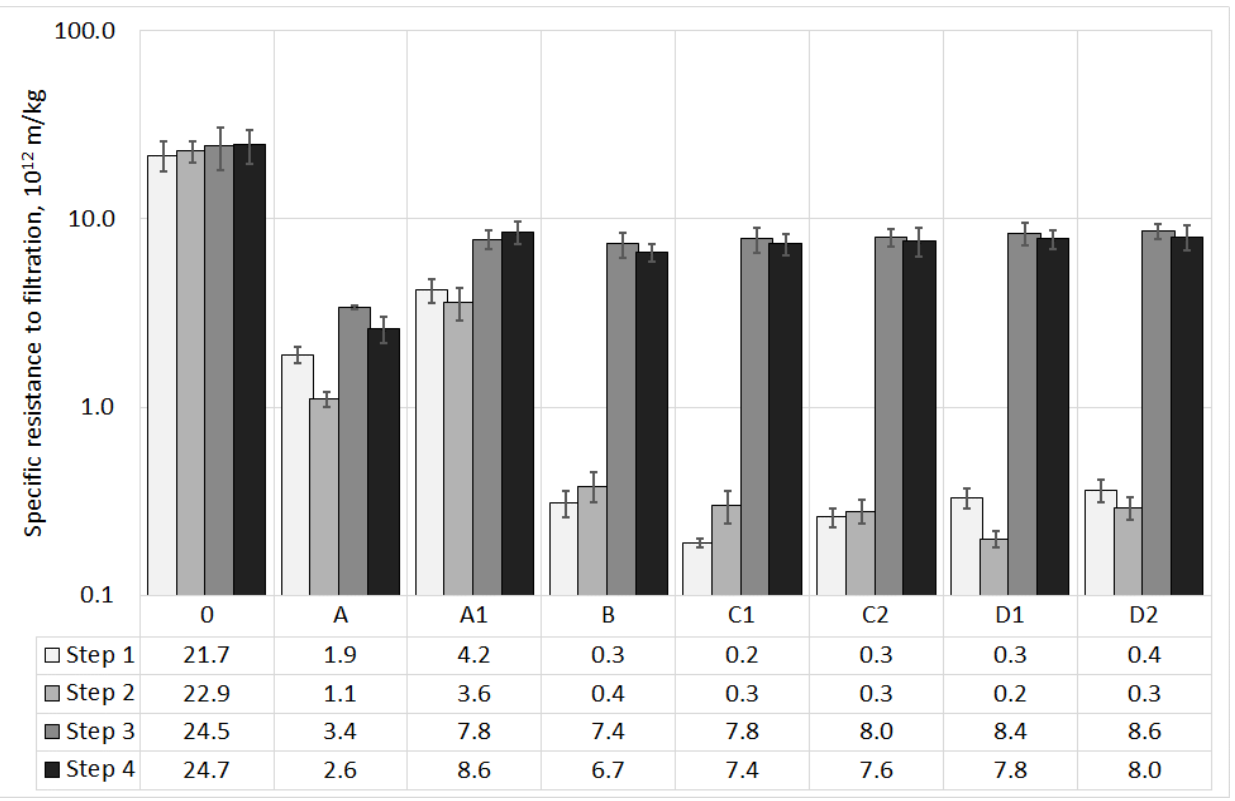

Fig. 2. Specific resistance to filtration of chemical and magnetically prepared sludge. 
Similar tendencies were observed for the final hydration of filter cake (Figure 3). The use of iron nanoparticles in the dual method (Step 3 - 4) resulted in increased final cake hydration compared to the use of PIX 113 (Step 1 - 2). The effects of the sludge's exposure to the magnetic field were variable. The most favorable results, as was the case for the specific resistance to filtration, were achieved for the $\mathrm{C} 1$ combination in step 1 .

An analysis of the supernatants was made for the selected combinations. Its exponent was the COD value (Figure 4). It was noted that centrifugation of the dually conditioned sludge generated leachate of a lower COD compared to sludge prepared with only polyelectrolyte. The sludge exposure to the magnetic field has positively influenced the quality of the leachate. It should be noted that the type of polyelectrolyte affects the quality of leachate. The least polluted were the liquids generated by the sludge prepared with coagulant PIX 113 and polymer C - 494, and subjected to magnetic field exposure with the following process parameters: flow velocity $1.0 \mathrm{~L} / \mathrm{min}$, flow direction: $\mathrm{S}-\mathrm{N}$.

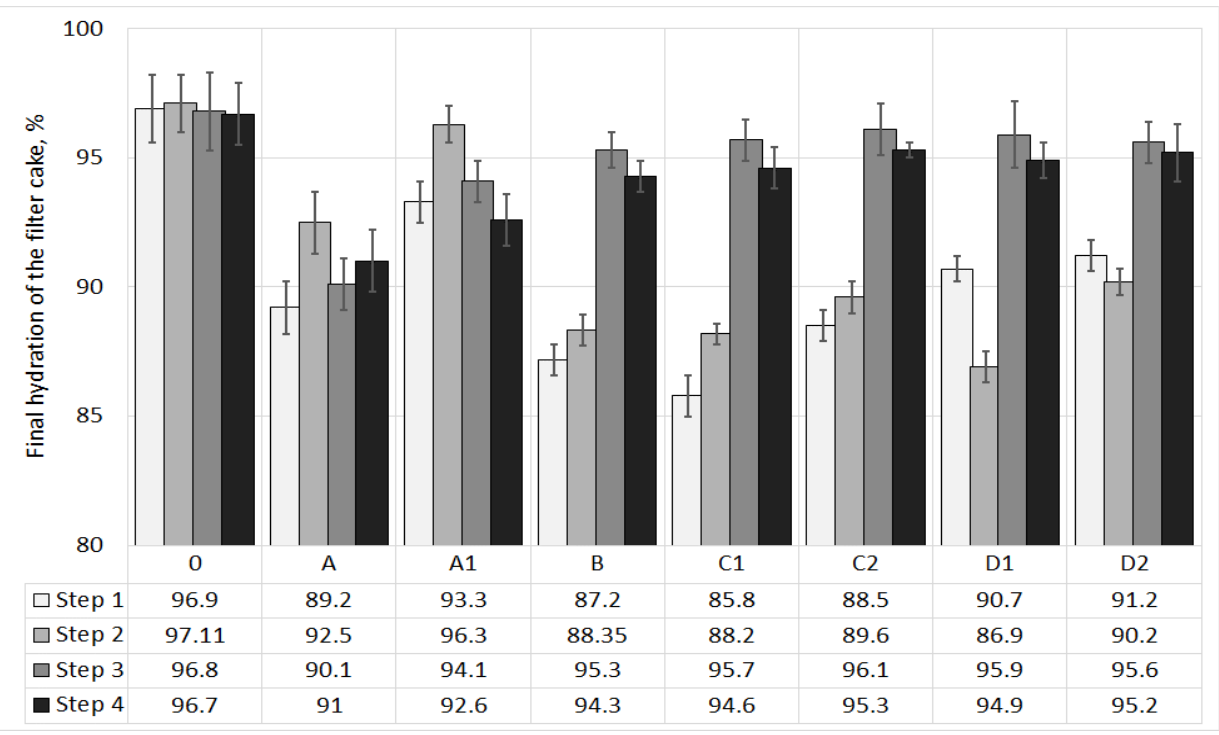

Fig. 3. Final hydration of the filter cake of the analyzed samples.

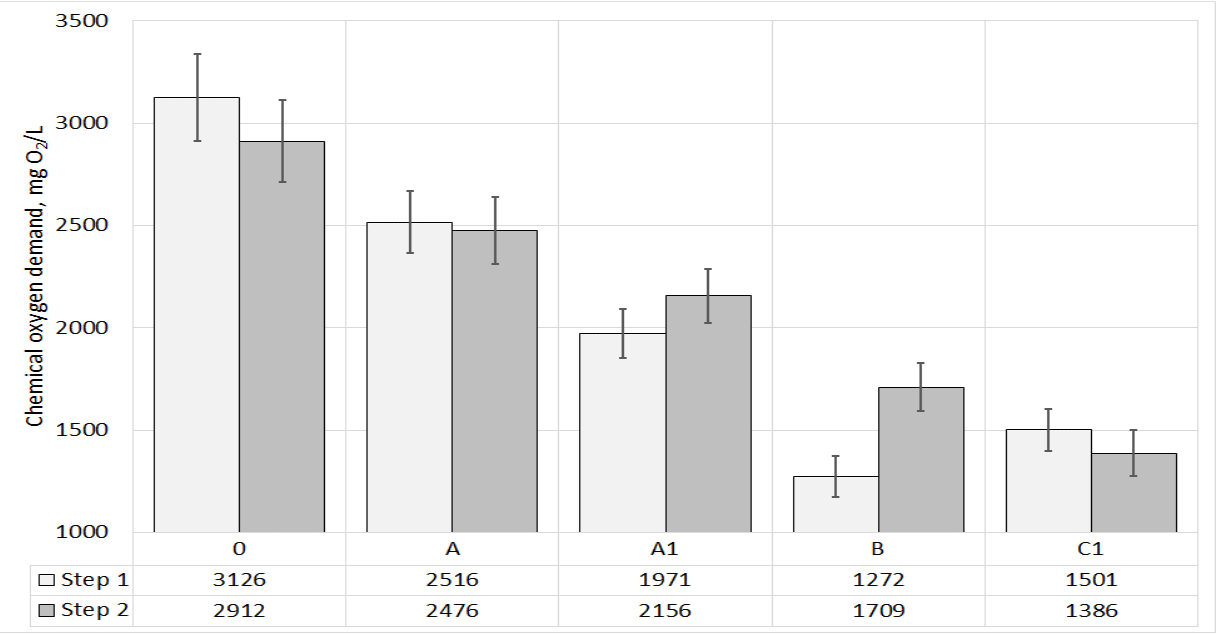

Fig. 4. The COD of leachate after centrifugation of the conditioned sludge. 


\section{Conclusions}

Based on the obtained results, the possibility of using nanoparticles (of the type tested) in the conditioning process was definitely rejected. The dual method based on the sequential use of the polyelectrolyte - PIX 113 was definitely preferred. Effective conditioning occurs when iron particles are included in the sludge structure as was the case with the use of ferric coagulant.

The influence of the magnetic field on the analyzed parameters was variable, depending on process parameters such as the direction and rate of sludge flow through the solenoid. The most favorable results were obtained for the hybrid prepared sludge using a C - 494 polymer subjected to a magnetic field with the following parameters: flow direction $\mathrm{S}-\mathrm{N}$, flow rate $1.0 \mathrm{~L} / \mathrm{min}$. In this case, indicators such as the capillary suction time and the specific resistance of filtration were reduced by 26 and 59\% respectively in comparison to identically prepared sludge not exposed to magnetic field (combination B). Slightly weaker effects (decrease of CST and $\mathrm{r}$ by 48 and $26 \%$ respectively) were achieved by sludge conditioning with polyelectrolyte $\mathrm{C}-496$ and subjecting them to the magnetic field at $\mathrm{N}-\mathrm{S}$ flow direction and a flow rate of $1.0 \mathrm{~L} / \mathrm{min}$. A flow rate of $2.0 \mathrm{~L} / \mathrm{min}$ in both cases was not favorable. This proves that the selection of optimal process parameters depends on the type of polyelectrolyte. In the studied multi-factor conditioning method, it is therefore recommended to first optimize the dual conditioning method, and in the next step to optimize the sludge flow in the magnetic field.

The exposure of sludge to the magnetic field also had a positive effect on the quality of leachates, expressed as COD. This is particularly important because the supernatants are recycled into the technological wastewater treatment process, thereby increasing the substrate load of the activated sludge.

The results of these preliminary studies proved that a magnetic field can be an effective agent for supporting the dual chemical conditioning of digested sludge. Further research will be limited to a narrower range of variables and extended to include other quantitative and qualitative indicators.

This work was supported by grant No. BSMN - 401 - 303/17 and BSPB 401 - 301/17 11 (Faculty of Infrastructure and Environment, Czestochowa University of Technology).

\section{References}

1. Główny Urząd Statystyczny, Bank Danych Lokalnych (2017)

2. L. Wolny Ultradźwiękowe wspomaganie procesu przygotowania osadów ściekowych do odwadniania, Seria Monografie nr 104, Wyd. Politechniki Częstochowskiej, Częstochowa (2005).

3. J.B. Bień, M. Kacprzak, T. Kamizela, M. Kowalczyk, E. Neczaj, T. Pająk, K. Wystalska, Komunalne osady ściekowe - zagospodarowanie energetyczne i przyrodnicze. Wyd. Politechniki Częstochowskiej, Częstochowa (2015)

4. J.B. Bień, M. Gałwa - Widera, T. Kamizela, M. Kowalczyk, K. Wystalska, Gospodarka osadami ściekowymi i uciążliwości zapachowe $w$ matych $i$ średnich oczyszczalniach ścieków, Wyd. Politechniki Częstochowskiej, Częstochowa (2016)

5. D. Mowla, H.N. Tran, D.G..Allen, Biomass Bioenergy, 58, 365-378 (2013)

6. Y. Qi, K.B. Thapa, A.F.A. Hoadley, Chem. Eng. J., 171, 373-384 (2011)

7. J. Bień, M. Strzelczyk, T. Kamizela, Inż. Och. Środ., 1-2, 17-26 (2000)

8. M. Siadaty, S. Kheradmand, F. Ghadiri, J. Aero. Sci., 114, 219-232 (2017) 
9. P. Zhao, J. Xie, F. Gua, N. Sharmin, P. Hall, J. Fu, Was. Man., (to be published, 2018)

10. H. Yavuz, S.S. Celebi, Enzyme Microb. Technol., 26, 22-27 (2000)

11. M. Łebkowska, A. Rutkowska-Narożniak, E. Pajor, Z. Pochanke, Bioresour. Technol., 102, 8777-8782 (2011)

12. Z. Wang, X. Liu, S.-Q. Ni, J. Zhang, X. Zhang, H. A. Ahmad, B. Gao, Water Res., 120, 190-198 (2017)

13. R. Lakshmanan, G. Kuttuva Rajarao, , Bioresour. Technol., 153, 333-339 (2014)

14. M. Zieliński, P. Rusanowska, M. Dębowski, A. Hajduk, Sci. Tot. Env., 625, 738-742 (2018)

15. H. Tanaka, Y. Uno, S. Morisada, K. Ohto, H. Kawakita, Chem. Eng. Process., 110, 128133 (2016)

16. G. Simonsen, M. Strand, G. Øye, J. Petrol. Sci. Engine., 165, 488-495 (2018)

17. W. Yantasee, C.L. Warner, T. Sangvanich, R.S. Addleman, T.G. Carter, R.J. Wiacek, G.E. Fryxell, C. Timchalk, M.G. Warner, Environ. Sci. Technol. 41, 5114 5119 (2007).

18. M.R. Mehrnia, M. Homayoonfal, J. Membr. Sci., 520, 881-894 (2016)

19. Characterization of sludge - Filtration properties - Part 1: Capillary Suction Time (CST), PN-EN 14701-1:2007.

20. Characterization of sludge - Filtration properties - Part 2: Determination of specific resistance to filtration, PN-EN 14701-2:2013-07 